\title{
Glutamatergic Control of Microvascular Tone by Distinct GABA Neurons in the Cerebellum
}

\author{
Armelle Rancillac, ${ }^{1}$ Jean Rossier, ${ }^{1}$ Manon Guille, ${ }^{2}$ Xin-Kang Tong, ${ }^{3}$ Hélène Geoffroy, ${ }^{1}$ Christian Amatore, ${ }^{2}$ \\ Stéphane Arbault, ${ }^{2}$ Edith Hamel, ${ }^{3}$ and Bruno Cauli ${ }^{1}$ \\ ${ }^{1}$ Laboratoire de Neurobiologie et Diversité Cellulaire, Centre National de la Recherche Scientifique (CNRS), Unité Mixte de Recherche (UMR) 7637, Ecole \\ Supérieure de Physique et de Chimie Industrielles de la ville de Paris, and 2Laboratoire "Processus d'Activation Sélective par Transfert d’Energie Uni- \\ électronique ou Radiatif," CNRS, UMR 8640, Université Pierre et Marie Curie, Ecole Normale Supérieure, 75005 Paris, France, and ${ }^{3}$ Laboratory of \\ Cerebrovascular Research, Montreal Neurological Institute, McGill University, Montréal, Québec, Canada H3A 2B4
}

The tight coupling between increased neuronal activity and local cerebral blood flow, known as functional hyperemia, is essential for normal brain function. However, its cellular and molecular mechanisms remain poorly understood. In the cerebellum, functional hyperemia depends almost exclusively on nitric oxide (NO). Here, we investigated the role of different neuronal populations in the control of microvascular tone by in situ amperometric detection of $\mathrm{NO}$ and infrared videomicroscopy of microvessel movements in rat cerebellar slices. Bath application of an NO donor induced both NO flux and vasodilation. Surprisingly, endogenous release of NO elicited by glutamate was accompanied by vasoconstriction that was abolished by inhibition of $\mathrm{Ca}^{2+}$-phopholipase $\mathrm{A} 2$ and impaired by cyclooxygenase and thromboxane synthase inhibition and endothelin A receptor blockade, indicating a role for prostanoids and endothelin 1 in this response. Interestingly, direct stimulation of single endothelin 1-immunopositive Purkinje cells elicited constriction of neighboring microvessels. In contrast to glutamate, NMDA induced both NO flux and vasodilation that were abolished by treatment with a NO synthase inhibitor or with tetrodotoxin. These findings indicate that $\mathrm{NO}$ derived from neuronal origin is necessary for vasodilation induced by NMDA and, furthermore, that NO-producing interneurons mediate this vasomotor response. Correspondingly, electrophysiological stimulation of single nitrergic stellate cells by patch clamp was sufficient to release NO and dilate both intraparenchymal and upstream pial microvessels. These findings demonstrate that cerebellar stellate and Purkinje cells dilate and constrict, respectively, neighboring microvessels and highlight distinct roles for different neurons in neurovascular coupling.

Key words: stellate cells; Purkinje cells; N0; amperometry; patch clamp; sphincter

\section{Introduction}

The tight coupling between neuronal activity and cerebral blood flow $(\mathrm{CBF})$, known as functional hyperemia, is a complex phenomenon that was first described more than a century ago (Roy and Sherrington, 1890). Despite this, its molecular and cellular mechanisms remain poorly elucidated. A key molecule in neurovascular coupling is nitric oxide $(\mathrm{NO})$, which has been identified as both a mediator and modulator of vascular responses that accompany increased neuronal activity (Iadecola and Zhang, 1996; Lindauer et al., 1999). In the cerebellum, functional hyperemia is dissociated from the spiking of principal neurons, the Purkinje cells (Caesar et al., 2003; Thomsen et al., 2004), and relies almost exclusively on release of the potent vasodilator NO

Received July 28, 2005; revised April 14, 2006; accepted April 28, 2006.

This work was supported by the Canadian Institutes of Health Research (Grant MOP-53334 to E.H.) and an exchange program (E.H. and B.C.) from les Fonds de la Recherche en Santé du Québec-Institut National de la Santé et de la Recherche Médicale. The Ecole Normale Supérieure (ENS) was supported in part by the Centre National de la Recherche Scientifique (Unité Mixte de Recherche 8640, Université Pierre et Marie Curie) and the Ministère de la Recherche (ENS). A.R. was supported by a fellowship from la Fondation pour la Recherche Medicale. We thank Tim Auman for comments.

Correspondence should be addressed to Dr. Bruno Cauli, Neurobiologie et Diversité Cellulaire, Unité Mixte de Recherche 7637, 10 rue Vauquelin, 75005 Paris, France. E-mail: bruno.cauli@espci.fr.

DOI:10.1523/JNEUROSCI.5515-05.2006

Copyright $\odot 2006$ Society for Neuroscience $\quad$ 0270-6474/06/266997-10\$15.00/0
(Yang et al., 1999). Hence, the increased cerebellar blood flow driven by stimulation of glutamate-releasing trigeminal sensory afferents that reach the cerebellum via the climbing fibers is virtually abolished by selective inhibition of neuronal NO synthase (nNOS or NOS-1) (Yang et al., 1999). Neuronal release of NO after glutamate receptor activation seems the most likely mediator of functional hyperemia in the cerebellum. Therefore, because NOS-1 is expressed by local stellate, basket, and granule cells, but not Purkinje cells (Rodrigo et al., 1994), these observations suggest that, akin to the neocortex (Cauli et al., 2004), interneurons are involved in local control of CBF. Consistent with this idea, cyclin D2-null mice that lack a major proportion of stellate cells in the molecular layer of the cerebellar cortex show a severely impaired functional hyperemic response to sensory stimulation (Yang et al., 2000).

Both NMDA (Southam et al., 1991; Fergus and Lee, 1997; Lovick et al., 1999) and non-NMDA (Yang et al., 1999) receptors have been implicated in the NO-dependent microvascular dilation induced by glutamate. Stellate cells are particularly enriched with extrasynaptic NMDA receptors (Carter and Regehr, 2000; Clark and Cull-Candy, 2002; Rancillac and Crepel, 2004). It is also possible that stimulation of glutamatergic pathways could alter blood vessel tone via activation of glial cells, which have 
recently been shown to release vasoactive signaling molecules and induce either vasodilation or vasoconstriction concomitantly with increased $\mathrm{Ca}^{2+}$ transients in their perivascular endfeet (Zonta et al., 2003; Filosa et al., 2004; Mulligan and MacVicar, 2004).

In the present study, we investigated changes in microvascular tone after pharmacological activation of glutamate receptors or single-cell-evoked firing by patch-clamp stimulations of single stellate or Purkinje cells in acute slices of rat cerebellum. We quantified NO release after single neuron activation and identified signaling molecules involved in the resulting vasomotor response. NO release was detected via amperometric measurements (Amatore et al., 2006) and the associated vasomotor responses monitored by infrared videomicroscopy (Sagher et al., 1993; Cauli et al., 2004).

\section{Materials and Methods}

Animals. Male Wistar rats (14-21 d old; Charles River, L'Arbresle, France) were used for recordings and immunofluorescence of injected neurons in rat acute cerebellar slices. All animals were housed in a temperature-controlled $\left(21-25^{\circ} \mathrm{C}\right)$ room under daylight conditions and had ad libitum access to food and water. Experiments were approved by the institution's animal ethics committee.

Slice preparation and electrophysiological recordings. Parasagittal slices (300 $\mu \mathrm{m}$ thick) of cerebellar vermis were cut with a Vibratome (VT1000S; Leica, Nussloch, Germany), transferred to a chamber, and perfused (1-2 $\mathrm{ml} / \mathrm{min}$ ) with oxygenated artificial CSF, essentially as described previously (Cauli et al., 1997). Patch pipettes (4-8 M $\Omega$ ) pulled from borosilicate glass were filled with internal solution containing 144 mm K-gluconate, 3 mm $\mathrm{MgCl}_{2}$, 0.2 mм EGTA, 10 mм HEPES, pH 7.2 (285/295 mOsm), and $2 \mathrm{mg} / \mathrm{ml}$ biocytin (Sigma, St. Louis, MO) for intracellular labeling. Neurons and blood vessels were located in the slice using infrared videomicroscopy with Dodt gradient contrast optics. Whole-cell recordings of selected cells were performed at $20-25^{\circ} \mathrm{C}$ or at $30-35^{\circ} \mathrm{C}$ using a patch-clamp amplifier (Axopatch 200A; Molecular Devices, Foster City, CA). Resting membrane potential and action potential discharges (using the I-clamp fast mode of the amplifier) were digitized and analyzed using pCLAMP 9 software (Molecular Devices).

Amperometric detection of NO. NO was detected by amperometry using platinized carbon fiber microelectrodes fabricated as described previously (Amatore et al., 2006). NO release in slices was measured at a constant potential maintained with a potentiostat (AMU130; TacusselRadiometer Analytical, Copenhagen, Denmark). Because of their large porous surface, platinized carbon-fiber microelectrodes slowly polarize. This capacitive phenomenon slightly drifts the baseline current. A custom computer program was developed to fit the drifting baseline current and subtract it from the entire response. Amperometric current attributable to the presence of NO was obtained by subtracting current responses at $+650 \mathrm{mV}$ versus sodium saturated calmel electrode (SSCE) (plateau of the oxidation wave for $\mathrm{NO}$ ) from those at $+450 \mathrm{mV}$ versus SSCE (foot of the oxidation wave for NO). Amperometric currents attributable to NO were converted into fluxes of NO release according to Faraday's law ( $I=n F \Phi$, where $n$ equals one electron per molecule exchanged for the oxidation of NO and $\Phi$ is the flux). Amperometric signals were digitized at $1 \mathrm{kHz}$ during pharmacological stimulations and at $10 \mathrm{kHz}$ during single-cell stimulations (Digidata 1322A converter and pCLAMP 9 software; Molecular Devices). The signals were then low-pass $(1 \mathrm{~Hz}$ ) filtered (Bessel, eight poles, $-3 \mathrm{~dB}$ ) using Clampfit software (Molecular Devices). Each platinized carbon-fiber microelectrode was used only once and was calibrated before and after each experiment by measuring the amplitude of its voltametric response [steady-state voltamogram at $20 \mathrm{mV} \cdot \mathrm{s}^{-1}$ between +200 and $+1000 \mathrm{mV}$ versus SSCE with a EI400 potentiostat (Ensman Instruments, Bloomington, IN)] in a pure nitrite solution (1 mM).

Drugs. Because of its short half-life $\left(16 \mathrm{~min}\right.$ at $\left.25^{\circ} \mathrm{C}\right)$, diethylammonium (Z)-1-( $N, N$-diethylamino)diazen-1-ium-1,2-diolate (DEANONOate; Alexis, San Diego, CA) was dissolved into the perfusion me- dium $10 \mathrm{~min}$ before a $5 \mathrm{~min}$ application. Glutamate agonists [i.e., glutamate, NMDA, trans-( \pm )-1-amino-1,3-cyclopentanedicarboxylic acid ( $t$-ACPD) or 2,5-dihydroxyphenylglycine (DHPG; Tocris Bioscience, Bristol, UK)] were bath perfused for $5 \mathrm{~min}$. To block NOS, phospholipase A2, cyclooxygenase, or thromboxane synthase activities, slices were treated for at least $1 \mathrm{~h}$ with $N \omega$-nitro-L-arginine (L-NAME; 1 mM; Sigma), methyl arachidonyl fluorophosphonate (MAPF; $100 \mu \mathrm{M}$; Sigma), aspirin (50 $\mu \mathrm{M}$; Sigma), or (2E)-3-[4-(1H-imidazol-1ylmethyl)phenyl]-2-propenoic acid hydrochloride (ozagrel, $100 \mu \mathrm{M}$; Tocris Bioscience). Soluble guanylyl cyclases (sGCs) were inhibited with $1 H$-[1,2,4] oxadiazolo[4,3-a] quinoxalin-1-one (ODQ; $10 \mu \mathrm{m}$; Sigma) 10 min before drug application. Blockade of neuronal activity, NMDA, or AMPA/kainate receptors was achieved with tetrodotoxin (TTX; $1 \mu \mathrm{M}$; Latoxan, Valence, France), D-(-)-2 amino-5-phosphonopentanoic acid (D-APV; $50 \mu \mathrm{M}$; Tocris Bioscience), or 6-cyano-7-nitroquinoxaline-2,3dione (CNQX; $10 \mu \mathrm{M}$; Tocris Bioscience), respectively. Group I metabotropic glutamate receptors (mGluRs) were blocked with a mixture of (S)-(+)- $\alpha$-amino-4-carboxy-2-methylbenzeneacetic acid (LY 367385) and 2-methyl-6-(phenylethynyl)pyridine hydrochloride (MPEP) (LY/ MPEP; $100 \mu \mathrm{M} / 50 \mu \mathrm{m}$; Tocris Bioscience), and group II-III mGluRs were blocked with $(R S)$ - $\alpha$-cyclopropyl-4-phosphonophenylglycine (CPPG; $100 \mu \mathrm{M}$; Tocris Bioscience). Endothelin $\mathrm{A}\left(\mathrm{ET}_{\mathrm{A}}\right)$ receptors were blocked with the selective antagonist cyclo(D- $\alpha$-aspartyl-L-prolyl-D-valyl-Lleucyl-D-tryptophyl) (BQ-123; $1 \mu \mathrm{M}$; Sigma), all blockers, were applied at least $5 \mathrm{~min}$ before glutamate agonist application. NO trapping was done by superfusing the slices with bovine hemoglobin ( $\mathrm{Hb} ; 4 \mu \mathrm{M}$; Sigma).

Vascular reactivity. Blood vessels with $>50 \mu \mathrm{m}$ of their length in focus and exhibiting a well defined luminal diameter $(8-30 \mu \mathrm{m})$ were selected for vascular reactivity. Images of blood vessels were acquired every $15 \mathrm{~s}$ using Image Pro Plus 5.0 (Media Cybernetics, San Diego, CA), and baselines were determined for $5 \mathrm{~min}$. Blood vessels with unstable baseline were discarded from the analyses. NMDA or DEA-NONOate (5 min) and current injection $(2 \mathrm{~min})$ were applied after a stable preconstriction (amounting to $56 \pm 7 \%$, mean $\pm \mathrm{SEM} ; n=9$ ) had been reached $[20 \mathrm{~min}$ after perfusion with the thromboxane A2 agonist 9,11-dideoxy-11a,9aepoxymethanoprostaglandin F2 $\alpha$ (U46619); $75 \mathrm{~nm}$. Single stellate or Purkinje cells in the vicinity $(<40 \mu \mathrm{m})$ of a selected vessel were recorded in whole-cell configuration and stimulated for $120 \mathrm{~s}$ by injection of 500 ms current pulses every second, eliciting a mean firing frequency of at least $10 \mathrm{~Hz}$ and left at their resting potential for the remaining of the experiment. Luminal diameters were measured manually off-line at different locations along the blood vessel identified with reference to landmarks in the tissue such as somata or smooth muscle cells.

Immunofluorescence. At the end of the recording period, slices containing biocytin-filled neuron were fixed by immersion in $4 \%$ paraformaldehyde $\left(6-18 \mathrm{~h} ; 4^{\circ} \mathrm{C}\right.$ in $0.1 \mathrm{~m}$ phosphate buffer). Cell morphology and their associations with reactive blood vessels (immunostained for laminin), perivascular glia [immunodetected for glial fibrillary acidic protein (GFAP)], and/or content in NOS-1 or endothelin 1 were assessed by double or triple immunofluorescence and confocal microscopy. Slices were first incubated with Streptavidin AlexaFluor 488 (1:1000; 15-30 min for stellate cells and $1-2 \mathrm{~h}$ for Purkinje cells; Invitrogen, Eugene, OR) for detection of biocytin-filled neurons and then overnight $\left(4^{\circ} \mathrm{C}\right)$ with an antibody against laminin (1:5000; Chemicon, Temecula, CA) detected with a mouse-specific Cy3-conjugated affiniPure secondary antibody (1: 200; Jackson ImmunoResearch, West Grove, PA). For NOS-1 immunoreactivity, slices were reincubated overnight with a rabbit anti-NOS-1 (1:1000; Upstate Biotechnology, Lake Placid, NY) antibody, rinsed, and incubated as above with mouse-specific Cy5-labeled secondary antibodies (1:200; Jackson ImmunoResearch). For immunostaining of endothelin 1 or GFAP after detection of the biocytin-injected Purkinje cell, sections were incubated (overnight) for laminin (as above) detected with a Cy5-conjugated secondary antibody, treated for antigen retrieval (Universal kit; R \& D Systems, Minneapolis, MN), and reincubated overnight for endothelin 1 (1:200, rabbit anti-endothelin 1; Pheonix Pharmaceuticals, Belmont, CA) immunostaining detected with a Cy3-conjugated secondary antibody. After confocal imaging, some endothelin 1-labeled sections were removed from the slides and reincubated overnight with rabbit anti-GFAP antibody (1:300; Dako, Mississauga, Ontario, Canada) 
detected with a Cy3-conjugated antibody, a treatment that resulted in the disappearance of the endothelin 1 immunostaining. Sections were then mounted again on microscope slides and rescanned for biocytin, laminin, and GFAP. Sections were observed under the confocal microscope (LSM 510; Zeiss, Thornwood, NY) using simultaneous double- or triplechannel detection with emission intensities of $488 \mathrm{~nm}$ (AlexaFluor), 543 $\mathrm{nm}(\mathrm{Cy} 3)$, and $640 \mathrm{~nm}$ (Cy5). Labeled neurons were scanned through their entire thickness, and their neuronal or astroglial vascular associations were examined in single-plane optical sections. Reconstruction $z$-stacks were used for figure representation of the neurons only, as described previously (Cauli et al., 2004).

Single-cell reverse-transcription PCR. Cytoplasm harvesting of recorded neurons and reverse transcription were performed as described previously (Lambolez et al., 1992). Patch pipettes were filled with $8 \mu \mathrm{l}$ of internal solution containing $144 \mathrm{~mm} \mathrm{~K}$-gluconate, $3 \mathrm{mM} \mathrm{MgCl}_{2}, 0.5 \mathrm{~mm}$ EGTA, $10 \mathrm{~mm}$ HEPES, and $2 \mathrm{mg} / \mathrm{ml}$ biocytin. The $\mathrm{pH}$ was adjusted to 7.2 , and osmolarity adjusted to $285 / 295 \mathrm{mOsm}$. At the end of the recording, as much as possible of the cell contents was aspirated into the recording pipette by application of a gentle negative pressure while maintaining the tight seal. The pipette was then delicately withdrawn to allow outside-out patch formation. Next, the contents of the pipette were expelled into a test tube, and reverse transcription was performed in a final volume of 10 $\mu$ l. Two steps of multiplex PCR were performed essentially as described previously (Cauli et al., 1997). cDNAs present in the $10 \mu \mathrm{l}$ reverse transcription reaction were first amplified simultaneously using all primer pairs designed to amplify cDNAs for glutamic acid decarboxylase 65 (GAD65) and GAD67, NOS-1, calbindin (CB), and parvalbumin (PV) (Price et al., 2005) (for each primer pair, the sense and antisense primers were positioned on two different exons). Taq polymerase (2.5 U; Qiagen, Hilden, Germany) and 20 pmol of each primer were added to the buffer supplied by the manufacturer (final volume, $100 \mu \mathrm{l}$ ), and $21 \mathrm{cycles}\left(94^{\circ} \mathrm{C}\right.$, $30 \mathrm{~s} ; 60^{\circ} \mathrm{C}, 30 \mathrm{~s} ; 72^{\circ} \mathrm{C}, 35 \mathrm{~s}$ ) of PCR were run. Second rounds of PCR were performed using $1 \mu \mathrm{l}$ of the first PCR product as a template. In this second round, each cDNA was amplified individually using its specific nested primer pair (Price et al., 2005) by performing 35 PCR cycles (as described above) and generating PCR fragments of 312, 509, 515, 249, and 342 bp for GAD65, GAD67, NOS-1, CB, and PV, respectively. Ten microliters of each individual PCR were then run on a $2 \%$ agarose gel using $\phi$ x174 digested by HaeIII as the molecular weight marker and stained with ethidium bromide.

Statistical analyses. To determine the statistical significance of vasomotor responses, changes in diameter were compared using a paired $t$ test at the time before onset of evoked firing or drug application in which the mean diameter change is closest to $0 \%$, and when the maximal response was observed. The effects of all pharmacological agents were evaluated using $t$ tests, taking the maximal response to glutamate or NMDA as the control condition. To determine the statistical significance of the NO flux, $t$ tests were used to compare NO flux at the time before the onset of evoked firing or drug application when mean NO flux is closest to 0 $\mathrm{fmol} / \mathrm{s}$ and when the maximal response was observed.

\section{Results}

NO flux and vascular responses induced by pharmacological stimulations

To investigate the functional role of $\mathrm{NO}$ in the control of vascular tone, detection of NO and its vasodilatory effect were first assessed by applying DEA-NONOate, a NO donor, in acute slices. Because blood vessels in the slice preparation lack intraluminal flow and pressure (Sagher et al., 1993; Cauli et al., 2004), vasodilations were detected in vessels preconstricted with the thromboxane agonist U46619 (75 nM) throughout the experiment. U46619 induced a slowly developing vasoconstriction of blood vessels that was often spatially restricted ( $n=9$ of 12 ) (Fig. $1 C, D$; see $4 C)$. When bath applied, DEA-NONOate $(100 \mu \mathrm{M})$ induced an NO flux of $0.83 \pm 0.07 \mathrm{fmol} / \mathrm{s}(n=5 ; p<0.001)$ (Fig. $1 A)$ and reversibly dilated microvessels to $86 \pm 28 \%$ over baseline $(p<$ $0.01 ; n=6$ ) (Fig. $1 B-D$ and supplemental video 1 , available at
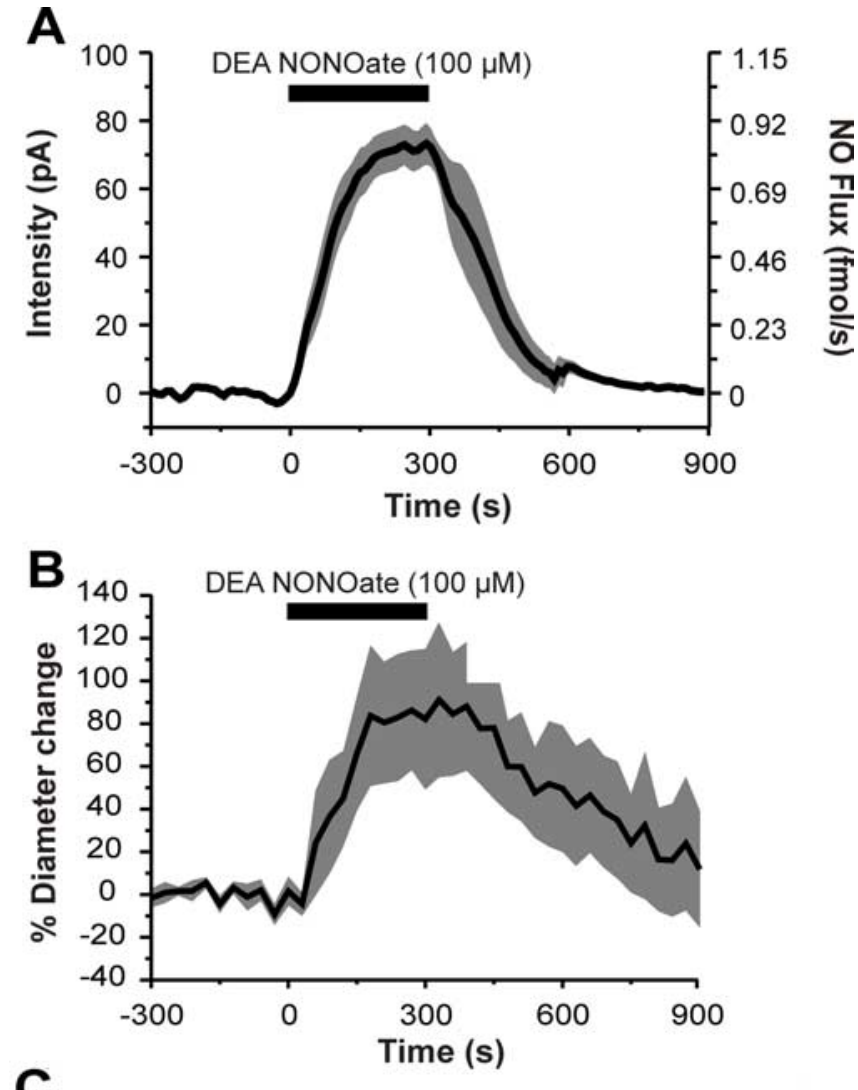

C

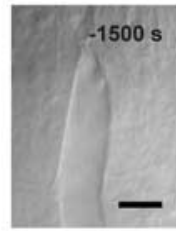

Initial

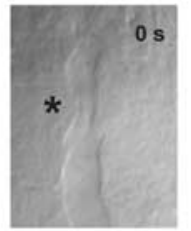

Preconstriction

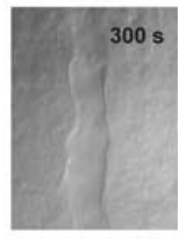

DEA NONOate

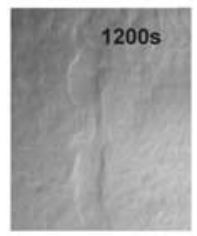

Recovery

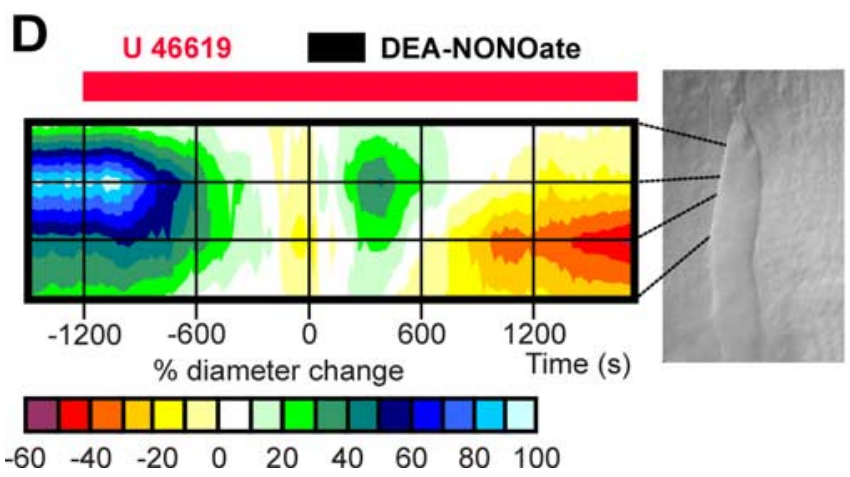

Figure 1. DEA-NONOate induces NO flux and vasodilations in cerebellar slices. $\boldsymbol{A}$, NO current (left axis) and corresponding NO flux (right axis) elicited by DEA-NONOate (100 $\mu \mathrm{M})$. The mean trace is surrounded by SEM values $(n=5)$. $\boldsymbol{B}$, Mean vascular dilation induced by DEA-NONOate $(n=6)$. The mean trace is surrounded by SEM values. $\boldsymbol{C}$, Images of an intraparenchymal cerebellar blood vessel that reversibly dilated to bath application of DEA-NONOate (100 $\mu \mathrm{m})$. Scale bar, $10 \mu \mathrm{m}$. The asterisk indicates a region of high vascular reactivity. $D$, Spatiotemporal analysis of the vascular response of the blood vessel shown in C. Black lines indicate the locations of measurements on the blood vessel. Note the spatially localized and progressive constriction (from blue to green) after U46619 (75 nm; red box) application that reversed to a dilation (from yellow-white to green, at $\sim 200-600 \mathrm{~s}$ ) under DEA-NONOate (100 $\mu \mathrm{m}$; black box). When DEA-NONOate was removed from the superfusion solution, the vessel reconstricted (from $\sim 700$ to 1800 s, yellow to red). 

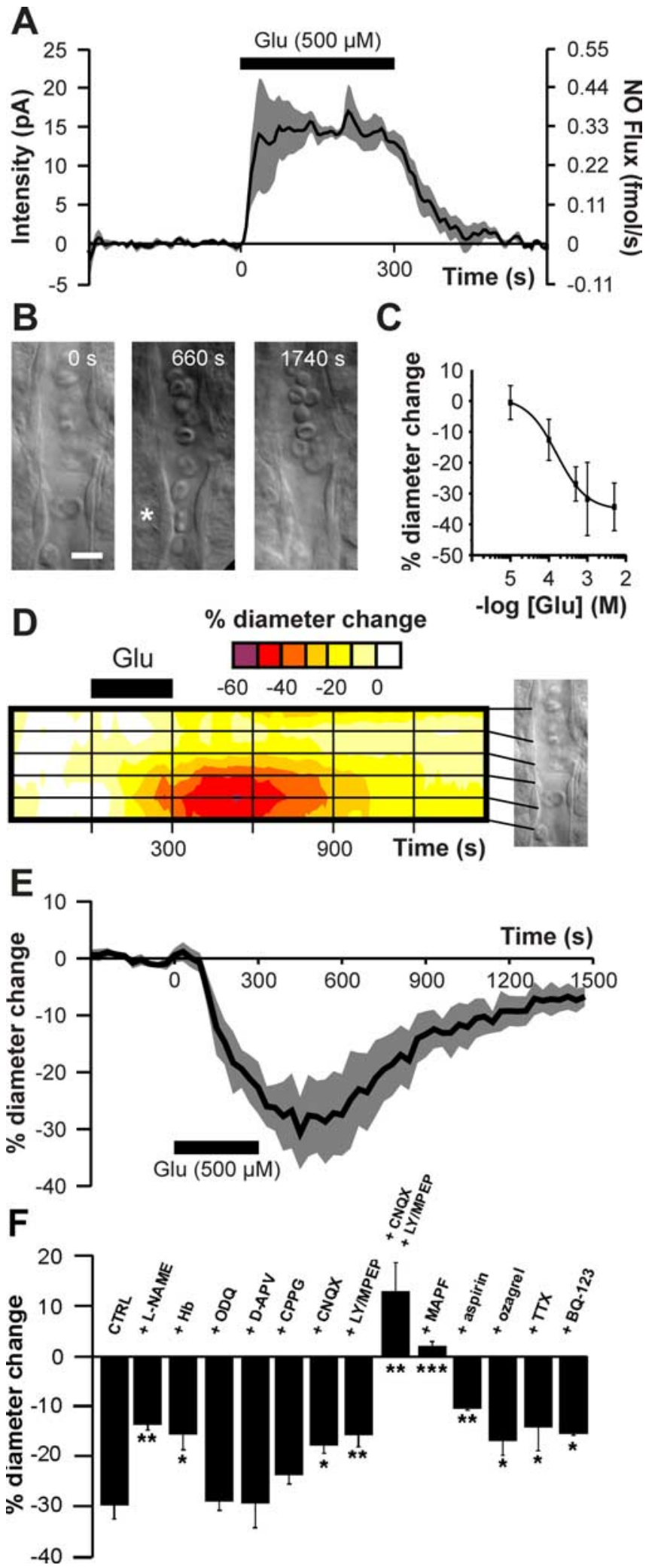

Figure 2. Glutamate induced NO flux and vasoconstrictions in cerebellar slices. $A$, NO current (left axis) and corresponding NO flux (right axis) elicited by glutamate (500 $\mu \mathrm{m}$ ). The mean trace is surrounded by SEM values $(n=5)$. $\boldsymbol{B}$, Images of an intraparenchymal cerebellar blood vessel that reversibly constricted to bath application of glutamate $(5 \mathrm{~mm})$. Scale bar, $10 \mu \mathrm{m}$. The asterisk indicates a region of high vascular reactivity. $C$, Dose-response curve of the glutamateinduced vasoconstriction. $\boldsymbol{D}$, Spatiotemporal analysis of the vascular response of the blood vessel shown in $\boldsymbol{B}$. Black lines indicate the locations of measurements on the blood vessel (right). Note the reversible and spatially restricted constriction after glutamate $(5 \mathrm{~mm}$; black box) application. $\boldsymbol{E}$, Mean vascular constrictions induced by glutamate $(500 \mu \mathrm{m} ; n=4)$. www.jneurosci.org as supplemental material). The dilatory response was more pronounced on the segment of blood vessel constricted most by U46619 (Fig. 1C,D). Inhibition of sGC by ODQ $(10 \mu \mathrm{M})$ abolished $(p<0.05)$ the dilations induced by DEA-NONOate $(-4+4 \% ; n=5)$, confirming that production of cGMP is necessary for NO-mediated vasodilation (Ignarro et al., 1999).

\section{Glutamate-induced constriction and Purkinje cell stimulation}

Glutamate was then applied to stimulate cerebellar neuronal networks and measure both neuronal release of $\mathrm{NO}$ and its vascular effect. Surprisingly, although glutamate $(500 \mu \mathrm{M})$ induced a transient NO flux of $0.32 \pm 0.04 \mathrm{fmol} / \mathrm{s}(n=5 ; p<0.001)$ (Fig. $2 A)$, it reversibly constricted $(-31 \pm 6 \% ; n=4$ of 4 tested vessels; $p<$ 0.05 ) (Fig. $2 E$ and supplementary video 2 , available at www. jneurosci.org as supplemental material) cerebellar blood vessels in a dose-dependent manner (mean $\mathrm{EC}_{50}, 160 \mu \mathrm{M}$ ) (Fig. 2C). The glutamate-induced vasoconstrictions were spatially restricted (Fig. $2 B, D$ ) and occurred whether or not $\mathrm{U} 46619$ was present in the superfusate (data not shown). Lowering basal NO levels by treatment with the NOS inhibitor L-NAME (1 mM) or with the $\mathrm{NO}$ scavenger $\mathrm{Hb}(4 \mu \mathrm{M})$ significantly reduced the glutamateinduced vasoconstriction (Fig. $2 F$ ). These results suggest that glutamate-induced microvascular contractions are enhanced in the presence of NO. Treatment with ODQ $(10 \mu \mathrm{M})$ did not alter the glutamate-induced vasoconstrictions (Fig. $2 F$ ), indicating that the enhancing effect of NO is not mediated by activation of $s$ GC. Stimulation of mGluRs with the agonist $t$-ACPD has been shown recently to induce astroglial-mediated constriction of hippocampal microvessels through the action of the arachidonic acid product 20-hydroxyeicosatetraenoic acid (20-HETE) (Mulligan and MacVicar, 2004). In cerebellar slices, application of t-ACPD $(200 \mu \mathrm{M})$ constricted cerebellar microvessels, but to a lesser extent than glutamate $(-14 \pm 4 \%$; $n=3$ of 4 tested vessels; $p<0.05)$. The group I mGluR agonist DHPG $(100 \mu \mathrm{M})$ produced only weak constriction in a minority of vessels $(-7 \pm 1 \% ; n=3$ of 7 tested vessels; $p<0.05$ ), suggesting either group I mGluRs do not contribute significantly to the glutamate-induced contractile response or that the latter involve multiple glutamate receptors. To address this question, the effects of different glutamate receptor antagonists on glutamate-induced constrictions were examined. Blockade of NMDA receptors by D-APV (50 $\mu \mathrm{M})$ or blockade of group II/III mGluRs by CPPG $(100 \mu \mathrm{M})$ did not alter glutamate-induced vasoconstriction (Fig. $2 F$ ), indicating that these receptors are not involved. In contrast, blockade of AMPA/ kainate receptors by CNQX $(10 \mu \mathrm{M})$ or blockade of group I mGluRs by LY/MPEP $(100 \mu \mathrm{M} / 50 \mu \mathrm{M})$ partially reduced the response (Fig. 2 F). Antagonism of both AMPA/kainite and group I mGluRs not only abolished the vasoconstrictions but reverted them to vasodilations (Fig. $2 F$ ), confirming that these two types of receptors mediate the glutamate-induced contractions. This treatment further disclosed the vasodilating effect of NO released by glutamate. Next the signaling pathway(s) as well as the cell

$\boldsymbol{F}$, Glutamate-induced constrictions $(500 \mu \mathrm{M})$ are not altered by D-APV $(50 \mu \mathrm{m} ; n=4)$ or CPPG (100 $\mu \mathrm{m} ; n=5)$ but are impaired by CNQX (10 $\mu \mathrm{m} ; n=5)$ or LY/MPEP $(100 \mu \mathrm{m} / 50 \mu \mathrm{m} ; n=$ 4) and reversed to dilation by coapplication of CNQX plus LY/MPEP $(n=3)$. Glutamate-induced constrictions are not affected by ODQ $(10 \mu \mathrm{m} ; n=5)$ but are attenuated in the presence of L-NAME (1 mм; $n=4), \mathrm{Hb}(4 \mu \mathrm{m} ; n=4)$, aspirin (50 $\mu \mathrm{m} ; n=3)$, ozagrel (100 $\mu \mathrm{m} ; n=4)$, TTX $(1 \mu \mathrm{m} ; n=5)$, and BQ-123 $(1 \mu \mathrm{m} ; n=3)$ and abolished by pretreatment with the phospholipase A2 inhibitor MAPF $(100 \mu \mathrm{m} ; n=4) .{ }^{*} p<0.05 ;{ }^{* *} p<0.01$. Glu, Glutamate. 

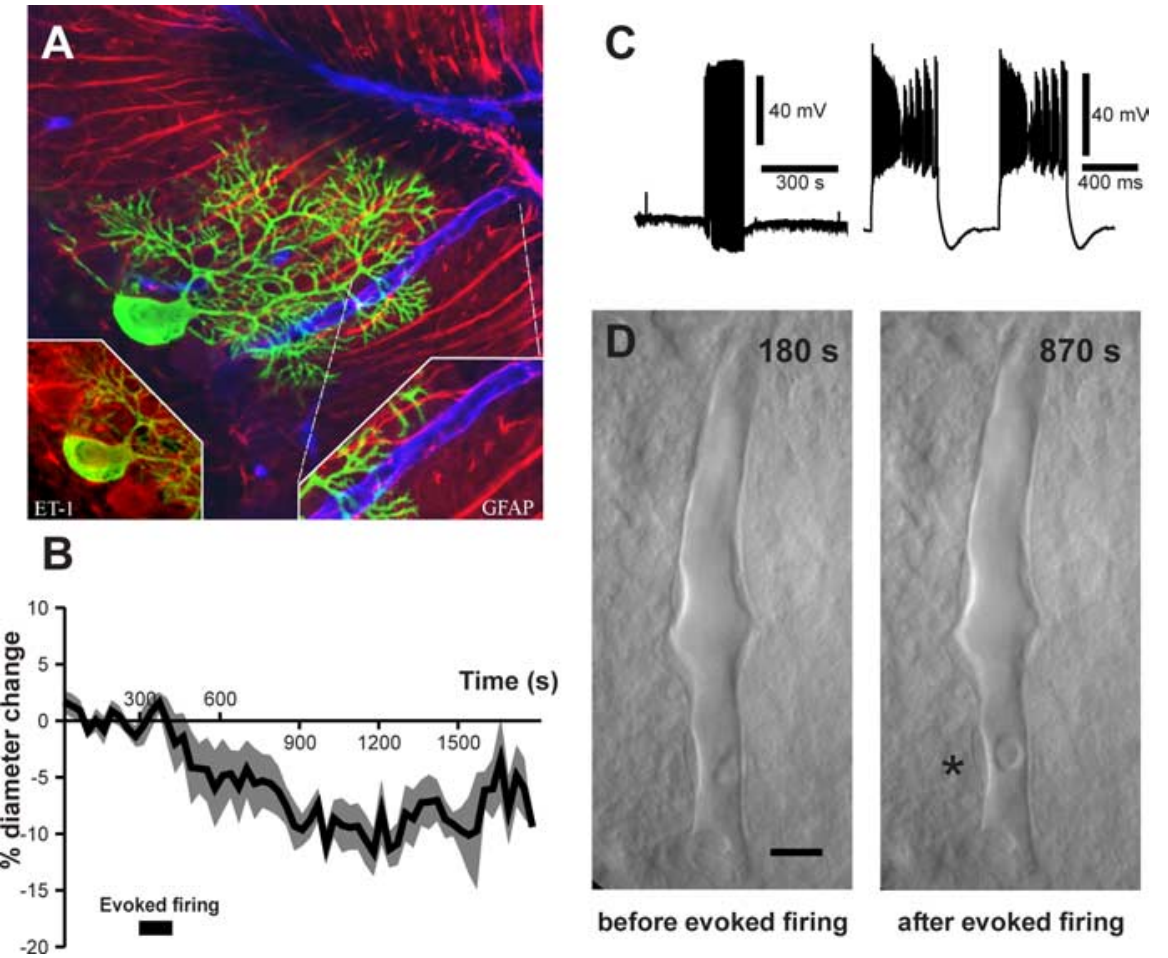

Figure 3. Purkinje cells express endothelin 1 and constrict microvessels. $A$, Confocal image of a recorded Purkinje cell (biocytin labeling; green) immunoreactive for endothelin 1 (ET-1; red; left inset) and located in the vicinity of penetrating blood vessels (immunodetected for laminin; blue). Note the processes of Bergmann glia ((immunodetected for GFAP; red) apposed to the blood vessel wall (right inset). $\boldsymbol{B}$, Mean vascular contraction induced by 2 min of evoked Purkinje cell firing (black box; $n=6$ ). The SEM borders the mean trace. $\boldsymbol{C}$, Electrophysiological recording of a Purkinje cell stimulated for $2 \mathrm{~min}$ (left trace). An example of trains of action potentials evoked during the stimulation paradigm of the Purkinje cell, showing complex spikes (right trace), is illustrated. $\boldsymbol{D}$, Infrared images of an intraparenchymal cerebellar blood vessel that constricted in response to the stimulation of a single Purkinje cell. Scale bar, $10 \mu \mathrm{m}$. The asterisk indicates a region of high vascular reactivity.

type(s) involved in glutamate-induced vasoconstriction were addressed. The response was virtually abolished (Fig. $2 \mathrm{~F}$ ) by MAPF $(100 \mu \mathrm{M})$, an inhibitor of the $\mathrm{Ca}^{2+}$-sensitive phospholipase $\mathrm{A}_{2}$ that releases arachidonic acid from membrane phospholipids and that is expressed by both glia (Stephenson et al., 1994) and Purkinje cells (Pardue et al., 2003). In addition to 20-HETE, arachidonic acid is also the precursor of another potent vasoconstrictor, namely thromboxane $\mathrm{A}_{2}$ synthesized by cyclooxygenase and thromboxane synthase (Funk, 2001). Aspirin (50 $\mu \mathrm{M})$ and ozagrel $(100 \mu \mathrm{M})$, respective inhibitors of these enzymes, significantly reduced (Fig. $2 F$ ) but did not abolish the glutamateinduced contractile response. These results indicate that prostanoids, likely thromboxane $\mathrm{A}_{2}$, are partially involved in the glutamate-induced constriction. The participation of neurons in this response was confirmed in slices preincubated with TTX (1 $\mu \mathrm{M})$, which significantly inhibited, albeit partially, the vasoconstriction (Fig. $2 \mathrm{~F}$ ). This partial inhibition suggests the contribution of cell types other than neurons (e.g., glia) and/or of Purkinje cells through TTX-resistant dendritic action potentials (Llinas and Sugimori, 1980). In this regard, Purkinje cells express endothelin 1 (Sluck et al., 1999), a potent vasoconstrictor of cerebellar microvessels (Sagher et al., 1993) that acts via $\mathrm{ET}_{\mathrm{A}}$ receptors (Sagher et al., 1994). Blockade of these receptors with the selective antagonist BQ-123 (1 $\mu \mathrm{M})$ significantly impaired the glutamateevoked vasoconstrictions (Fig. $2 F$ ). Moreover, confocal microscopy of immunofluorescent-stained sections revealed dendritic appositions of endothelin 1-positive biocytin-filled Purkinje cells onto intraparenchymal microvessels and associated perivascular glial endfeet (Fig. 3A). A direct constrictive effect of Purkinje cells was demonstrated by evoking firing of action potentials (Fig. $3 B-D)$ in single Purkinje cells $(n=9)$ located near intraparenchymal blood vessels. Such a stimulation induced vasoconstrictions $(-12 \pm 2 \% ; p<0.001 ; n=6$ of 9 cells) (Fig. $3 B$ ), indicating that increased neuronal activity in Purkinje cells results in contraction of intraparenchymal blood vessels. Together, these data strongly suggest that Purkinje cells and/or glia mediate the glutamate-induced vasoconstrictions through activation of mGluR and ionotropic non-NMDA glutamate receptors and the actions of arachidonic acid metabolites and endothelin 1.

\section{NMDA-induced vasodilation}

Glutamate acts via multiple receptor subtypes among which NMDA receptors are known to stimulate NO release from nitrergic neurons (Southam et al., 1991; Garthwaite and Boulton, 1995). Activation of this receptor subtype with the agonist NMDA has no direct effect on cerebral blood vessels (Faraci and Breese, 1993) but induces NO-mediated vasodilation in hippocampal slices (Fergus and Lee, 1997; Lovick et al., 1999). Moreover, the present study revealed that glutamate-induced vasoconstrictions are insensitive to NMDA receptor antagonism. Finally, Purkinje cells do not express functional NMDA receptors (Crepel et al., 1982), and, in contrast to glutamate, NMDA does not stimulate arachidonic acid release from astrocytes (Stella et al., 1994). Therefore, slices were stimulated with NMDA to assess the contribution of endogenously released neuronal NO in cerebellar dilation. Bath application of NMDA $(100 \mu \mathrm{M})$ induced a transient NO flux of $0.14 \pm$ $0.03 \mathrm{fmol} / \mathrm{s}(n=5 ; p<0.05)($ Fig. $4 A)$ that preceded a potent and reversible vasodilation $(51 \pm 17 \% ; n=6 ; p<0.05$ ) (Fig. $4 A-C$ and supplemental video 3 , available at www.jneurosci.org as supplemental material). As for DEA-NONOate-induced dilations, the effect of NMDA was more pronounced on the portion of the blood vessel that constricted most to U46619 (Fig. 4B,C). To further demonstrate the role of NO in NMDA-mediated vasodilation, slices were treated with L-NAME (1 mM) to block NOS activity. Under these conditions, NMDA did not elicit any detectable NO flux ( $n=5$; data not shown) or vasodilation $(n=4)$ (Fig. $4 A$ ), demonstrating that NOS activity is necessary for the NMDA-induced vasodilations. Furthermore, in slices incubated with TTX $(1 \mu \mathrm{M})$ to abolish neuronal activity, the NMDAinduced NO flux $(n=6$; data not shown) and accompanying vasodilation $(n=7)$ (Fig. $4 A$ ) were suppressed. These data demonstrate that nNOS activity is necessary for both NMDA-induced $\mathrm{NO}$ release and vasodilation, pointing to a role for NOproducing interneurons in the vascular response.

\section{Single stellate cell stimulation}

In contrast to other cerebellar NO-producing interneurons, stellate cells are superficially located in the molecular layer, an ideal position to dilate, via local NO diffusion, surface pial arteries and 


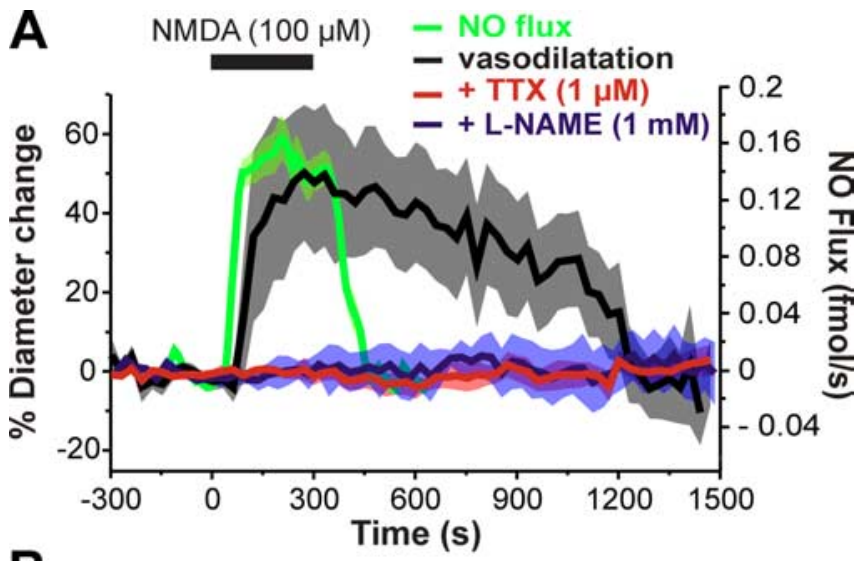

B
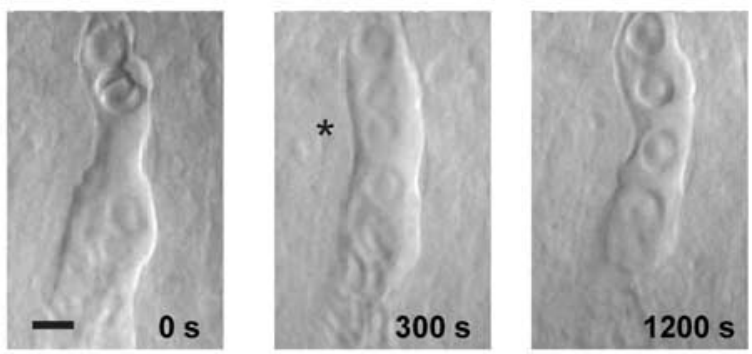

Preconstricted
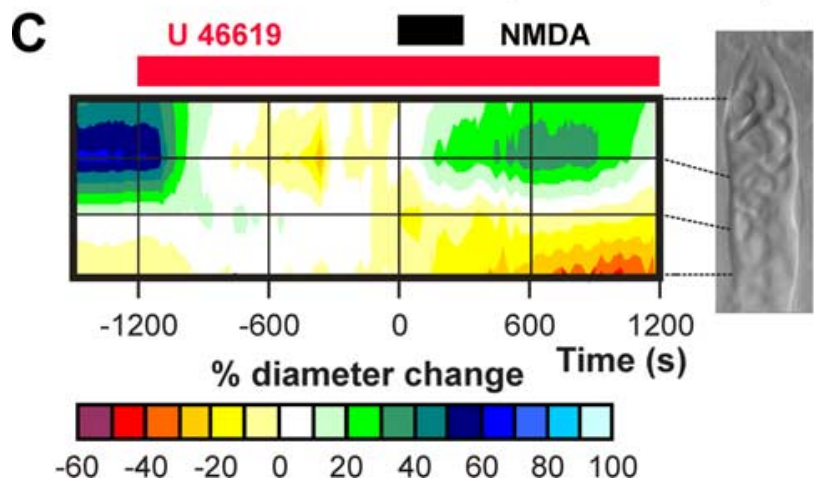

Figure 4. NO mediates the NMDA-induced vasodilations. $\boldsymbol{A}$, Left axis, The mean vascular dilation induced by NMDA ( $n=7$; black) is abolished by TTX ( $1 \mu \mathrm{m} ; n=7$; red) or L-NAME ( 1 $\mathrm{mm} ; n=4$; blue). Right axis, NO flux (green trace) elicited by NMDA $(n=5)$. The SEM envelopes the mean traces. $\boldsymbol{B}$, Infrared images of an intraparenchymal cerebellar blood vessel preconstricted with U46619 $(75 \mathrm{~nm})$ that reversibly dilated to NMDA (100 $\mu$ M) application. Scale bar, 10 $\mu \mathrm{m}$. The asterisk indicates a region of high vascular reactivity. C, Spatiotemporal response of the blood vessel shown in $\boldsymbol{B}$. Note the spatially restricted constriction (from blue to yellow) under U46619 (75 nм) application (red box) that reversed to a dilation (from yellow to green) after NMDA application (black box). Right, Infrared image of the blood vessel before U46619 application with the locations of measurements indicated by black lines.

downstream intraparenchymal branches, both needed to increase intraparenchymal blood flow (Iadecola, 2004). Stellate cells were first identified by their location in the outer one-third of the molecular layer, their small soma ( $8-9 \mu$ m diameter), their discharge pattern, their molecular profile, and finally by NOS and biocytin immunolabeling. Stellate cells exhibited typical discharge of spontaneous action potentials in a cell-attached configuration and spontaneous inhibitory postsynaptic currents in a whole-cell configuration, as described previously (Llano and Gerschenfeld, 1993). The expression of GAD65 and, to a lesser extent, GAD67 in stellate and Purkinje cells by single-cell RTPCR analysis confirmed their GABAergic nature (Fig. 5A, $B$ ). In good agreement with previous observations, $\mathrm{PV}$ was expressed in a majority of stellate and Purkinje cells and $\mathrm{CB}$ was expressed in all Purkinje cells (Fig. 5A,B) (Celio, 1990; Cauli et al., 1997; Bastianelli, 2003). Also, most recorded stellate cells, in contrast to Purkinje cells, expressed NOS-1 mRNAs ( $n=6$ of 7) (Fig. $5 A, B$ ) and protein (Fig. $5 C$ ). These observations confirmed the nitrergic nature of stellate cells and the paucity of NOS-1 expression in Purkinje cells (Rodrigo et al., 1994). To directly show the release of NO from stellate cells, an NO probe was placed in the vicinity $(<5 \mu \mathrm{m})$ of the recorded interneurons (Fig. $5 D$, inset) and firing of action potentials evoked by injecting depolarizing currents. The evoked firing of single stellate cells induced an NO flux of $0.018 \pm 0.007 \mathrm{fmol} / \mathrm{s}$ at $20-25^{\circ} \mathrm{C}$ that developed in phase with the evoked firing, reached a plateau within $30 \mathrm{~s}$, and recovered to baseline after the end of evoked firing $(n=4 ; p<0.05)$ (Fig. $5 D)$. Increasing the recording temperature to $30-35^{\circ} \mathrm{C}$ speeds up the onset $(n=5 ; p<0.05)$ and increase the steady-state level of NO flux to $0.047 \pm 0.024 \mathrm{fmol} / \mathrm{s}$ (NS) (Fig. 5D). In contrast to stellate cells, stimulation of Purkinje cells did not induce NO flux $(n=3$; $p>0.7$ ) (Fig. 5D).

The evoked-firing of single stellate cells induced (11 of 18) dilations of neighboring intraparenchymal microvessels at both $20-25^{\circ} \mathrm{C}$ and $30-35^{\circ} \mathrm{C}$. The dilations develop slowly and averaged $8 \pm 2 \%(n=6 ; p<0.001)$ (Fig. $6 A-C)$ at $20-25^{\circ} \mathrm{C}$ and $11 \pm$ $3 \%(n=5 ; p<0.05)$ at $30-35^{\circ} \mathrm{C}$. Increasing the recording temperature did not significantly alter the onset or the recovery of vasodilations (Fig. 6C). No correlation was found between the mean firing frequencies and the NO flux or the vasodilation (data not shown). Confocal microscopy analysis revealed the spatial relationship between a stimulated stellate cell and its projecting neurites with a responsive blood vessel (Fig. 6B). Dilations induced by evoked firing of stellate interneurons were also observed in pial vessels ( 4 of 10 stimulated cells). Figure $6 D$ is an example a stellate cell that locally dilated both neighboring pial and intraparenchymal microvessels (Fig. 6E).

\section{Discussion}

Exogenous application of an NO donor in acute cerebellar slices induced both NO flux and vasodilation as measured by amperometry and videomicroscopy, respectively. In contrast, nonselective pharmacological stimulation of neuronal networks with glutamate induced NO release but elicited vasoconstriction of local microvessels. This response was reduced by $\mathrm{Ca}^{2+}$ phopholipase $\mathrm{A} 2$, cyclooxygenase, or thromboxane synthase inhibition, $\mathrm{ET}_{\mathrm{A}}$ receptor antagonism, and TTX, suggesting a role for arachidonic acid metabolites and endothelin 1 released from either perivascular glia and/or Purkinje cells. Correspondingly, direct stimulation of Purkinje cells induced constriction of neighboring microvessels. On the other hand, pharmacological stimulation of cerebellar networks with NMDA induced NO flux and vasodilation, both of which were abolished by treatment with L-NAME or TTX. Moreover, direct stimulation of single nitrergic stellate cells induced NO release and dilation of neighboring pial and intraparenchymal microvessels. Together, the findings indicate the ability of distinct populations of neurons to differentially adjust cerebrovascular tone as a function of their neuronal activity.

\section{NO-mediated cerebellar vasodilation}

In the slice preparation, the lack of luminal flow that induces a constricting tone (Bryan et al., 2001) together with a high basal level of vasodilating agents (Fergus et al., 1996; Zonta et al., 2003) contribute primarily to a dilated state of the blood vessels. To counteract this, vasodilations are normally measured in pharmacologically preconstricted vessels (Sagher et al., 1993; Lovick et 
A

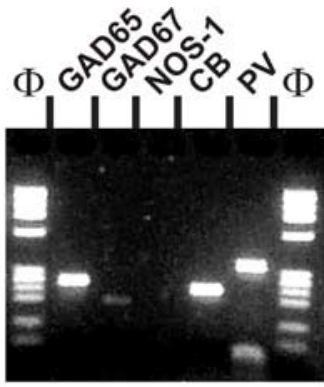

B

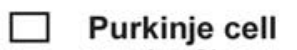
$(n=9)$

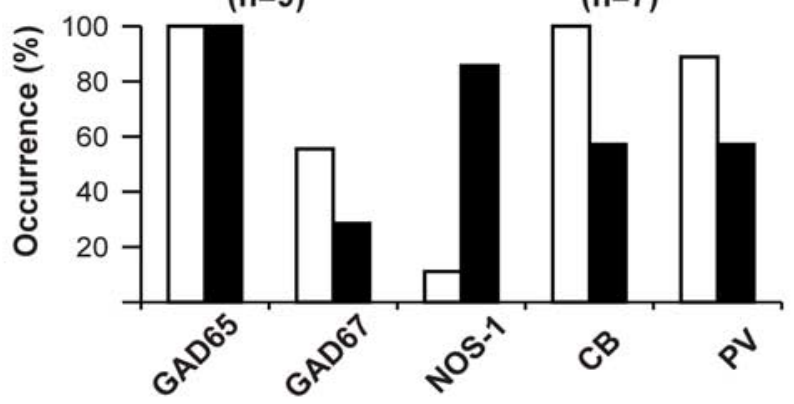

C

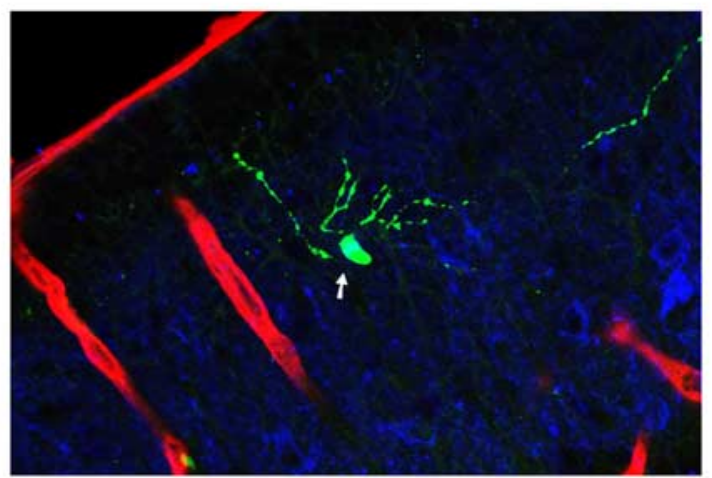

D

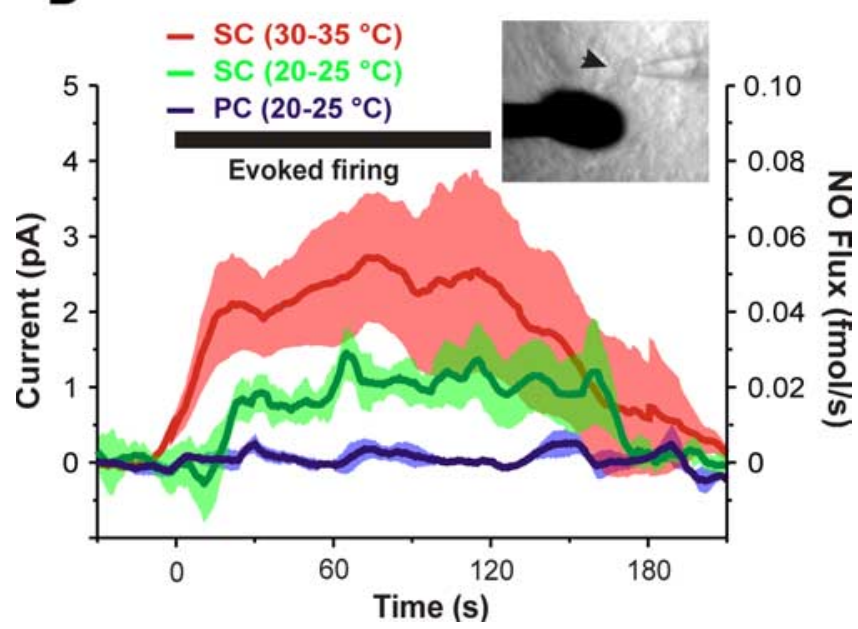

Figure 5. Stellate cells express NOS-1 and release NO. A, Molecular analysis of a representative Purkinje cell (expressing GAD65, GAD67, CB, and PV; left) and stellate cell (expressing GAD 65, GAD67, and NOS-1; right). B, Summary of single-cell RT-PCR analysis. NOS-1 was consistently expressed in stellate cells ( 6 of 7 ) but only rarely in Purkinje cells ( 1 of 9 ), with reliable expression of GAD65 and GAD67 in both cell types. Note also the high occurrence of $C B$ and PV in Purkinje cells. C, Confocal image of a recorded stellate interneuron (biocytin labeling; green) immunoreactive for NOS-1 (blue, merge is cyan; arrow) and located in the vicinity of penetrating blood vessels (immunodetected for laminin; red). $\boldsymbol{D}$, Left axis, Mean N0 current induced by 2 min evoked firing (black box) of stellate cells (SC) recorded at $20-25^{\circ} \mathrm{C}(n=4$; green) or al., 1999; Zonta et al., 2003). In our sampled vessels, we found that vasoconstrictions induced by U46619 or glutamate were often spatially localized along microvessel walls. Moreover, NOmediated dilations were more pronounced on portions of vessels that had constricted most to U46619. This dual control of blood vessel at strategic locations along their wall may highlight the importance of sphincter-like structures in the local distribution of flow within an activated area, as originally suggested in the neocortex (Cauli et al., 2004).

\section{Stellate cells induce NO-mediated dilation of cerebellar microvessels}

Stimulation of parallel fibers that excite stellate and basket cells induces dilation of both intraparenchymal and pial microvessels (Iadecola et al., 1997), but basket cells are presumably too deep in the molecular layer to contribute to the pial vessel response that is needed to increase intraparenchymal blood flow. In line with this, a previous study showed that cyclin D2 knock-out mice lacking stellate cells but not basket cells exhibit impaired NO-mediated functional hyperemia (Yang et al., 2000). The present study now clearly demonstrates that stellate cells mediate neurovascular coupling via NO release. Indeed, stellate cells that express extrasynaptic NMDA receptors (Carter and Regehr, 2000; Clark and Cull-Candy, 2002; Rancillac and Crepel, 2004) and NOS-1 (Rodrigo et al., 1994) released NO concomitantly with microvessel dilation when activated by bath-applied NMDA. This finding fully agrees with the previously reported NMDA-induced vasodilation of hippocampal microvessels via neuronally derived NO (Lovick et al., 1999). We show here that the evoked firing of single stellate cells is sufficient to induce both NO flux and vasodilation of intraparenchymal and pial microvessels. Assuming a single point source of NO release during single stellate cell-evoked firing, the sphere of influence has a diameter of $\sim 200 \mu \mathrm{m}$ (Wood and Garthwaite, 1994), which is compatible with control of both neighboring intraparenchymal and upstream pial vessels. We estimated that the amplitude of NO flux produced by the firing of a single stellate cell corresponds to an equivalent steady-state concentration of $0.3 \pm 0.1 \mu \mathrm{M}$. However, this value should be used with caution because the release of NO is from an undetermined number of local sources in an undetermined volume. Indeed, firing of action potentials evoked by injecting depolarizing currents in single NO neurons likely induced NO release from their widespread network of fine neuronal fibers (Philippides et al., 2005). Also, because stellate cells are electrically coupled (Galarreta and Hestrin, 2001), the coordinated firing of action potentials in these interneurons may synchronize the release of $\mathrm{NO}$, increasing the spreading of NO-mediated vasodilation at the intraparenchymal and pial level. Together, these results demonstrate that stellate cells, via NO release, are essential to link neuronal activity with blood flow in the cerebellum.

\section{Glutamate- and Purkinje cell-induced vasoconstriction: signaling molecules}

A most striking finding from our study was bath-applied glutamate and single Purkinje cells stimulation induced contraction of cerebellar microvessels. Because the constrictions were partially reduced by inhibition of prostanoids biosynthesis and blockade

$30-35^{\circ} \mathrm{C}(n=5$; red $)$ and of Purkinje cells $(P C)$ recorded at $20-25^{\circ} \mathrm{C}(n=3$; blue). Right axis, Equivalent NO flux. Mean traces are surrounded by the SEM. Inset, Location of the NO probe in the vicinity of a patched stellate cell (arrowhead). 
of $\mathrm{ET}_{\mathrm{A}}$ receptors, these findings suggest that two different signaling pathways, likely thromboxane $\mathrm{A}_{2}$ and endothelin 1, contribute to the contractile response. Indeed, both compounds constrict cerebellar microvessels (present study; Sagher et al., 1993). More specifically, the expression of endothelin 1 (Sluck et al., 1999) and of cyclooxygenase and phospholipase $\mathrm{A}_{2}$, biosynthetic enzymes of the vasocontractile derivative thromboxane $\mathrm{A}_{2}$, in Purkinje cells (Pardue et al., 2003), together with the finding that the evoked firing of these cells elicited vasoconstriction, strongly implicates them in the glutamateinduced vasoconstriction.

However, the opposite vasomotor effects of glutamate (contraction) and NMDA (dilation) on microvascular tone point to different glutamate receptors, likely located on different cell types, being involved in local regulation of cerebellar blood flow (Fig. 7). We found a greater release of NO in slices stimulated with glutamate compared with NMDA, indicating activation of non-NMDA receptors in the glutamate-induced NO release. Indeed, stellate cells, which express NMDA receptors (Rancillac and Crepel, 2004) whereas Purkinje (Crepel et al., 1982) and glial (Stella et al., 1994) cells do not, also express $\mathrm{Ca}^{2+}$-permeable AMPA receptors (Liu and Cull-Candy, 2000) and group I mGluRs (Grandes et al., 1994; Karakossian and Otis, 2004), and their concurrent activation by glutamate most likely explains, at least in part, the larger amounts of $\mathrm{NO}$ released by glutamate compared with NMDA. Yet, this larger NO release translated into cerebellar constrictions and not dilations, suggesting that the constriction elicited by the synthesis and release of contractile arachidonic acid derivatives from glia and/or neurons and of endothelin-1 from Purkinje cells predominates over the NO-induced dilation (Fig. 7).

The partial resistance of the contractile response to TTX suggests contribution from perivascular glia and the endfeet of GFAPpositive glial cells, including Bergmann glia (Fig. 3A). These were seen to be closely apposed to microvessels in the cerebellar cortex. The $\mathrm{Ca}^{2+}$-sensitive phospholipase $\mathrm{A}_{2}$ (Stephenson et al., 1994), group I mGluRs (Grandes et al., 1994; Berthele et al., 1999; Karakossian and Otis, 2004), as well as AMPA receptors (Lambolez et al., 1992; Petralia and Wenthold, 1992) are also expressed in Bergmann glia and Purkinje cells, and, after glutamate stimulation, both could release arachidonic acid that would preferentially be metabolized into vasoconstrictor products. Additionally, Purkinje cells display $\mathrm{Ca}^{2+}$ dependent and TTX-resistant dendritic action potentials (Llinas and Sugimori, 1980), making it possible that perivascular endothelin 1-positive dendrites of stimulated Purkinje cells (Fig. $3 A$ ) are actively involved in the contractile response.

A
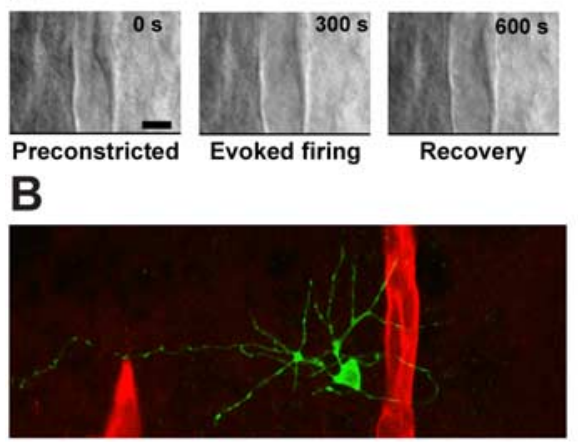

C
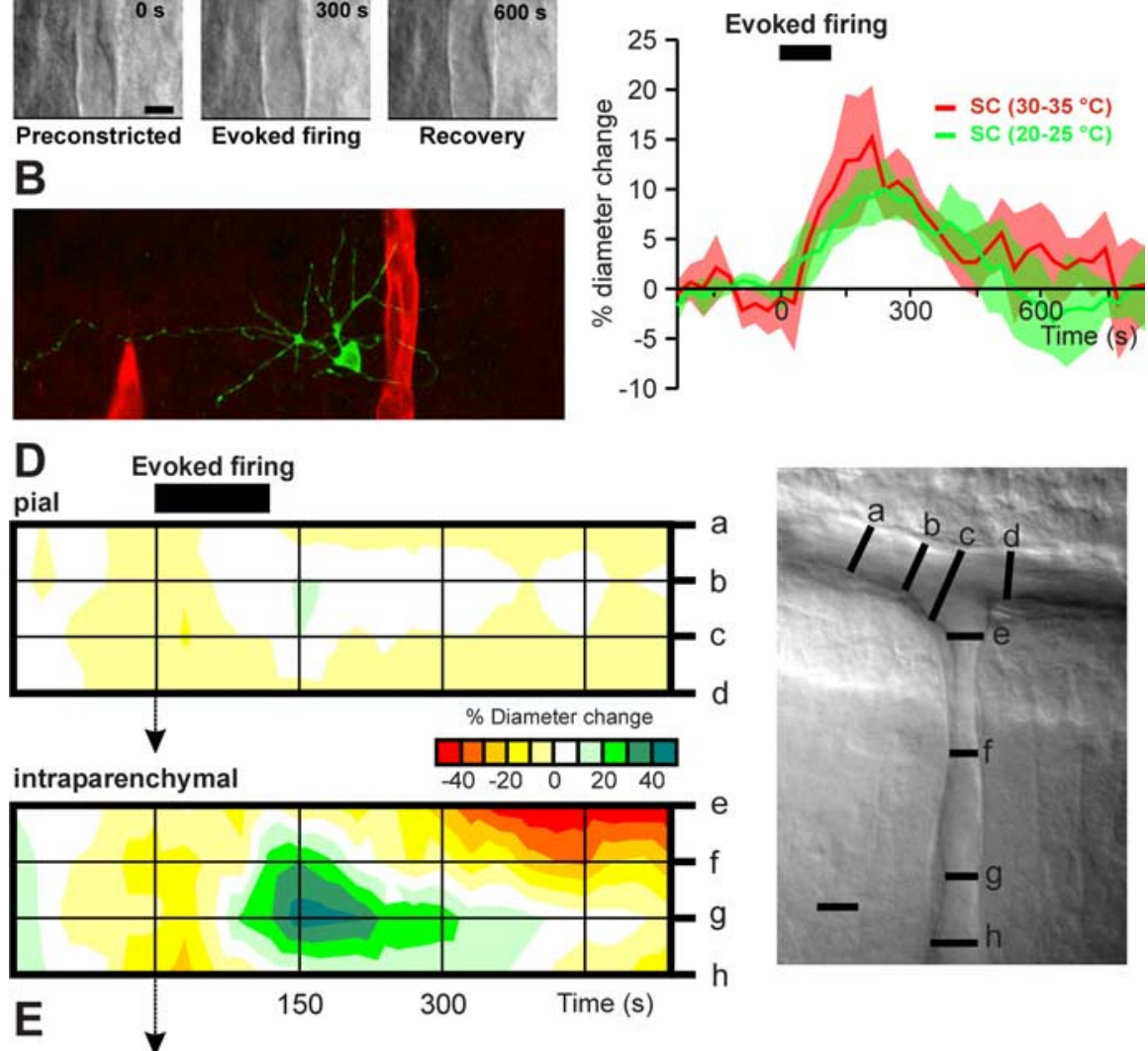

Figure 6. Single stellate cell-evoked firing dilates pial and intraparenchymal vessels. $\boldsymbol{A}$, Infrared images of a responsive microvessel to depolarization of a stellate cell illustrating diameter changes during the dilation. Scale bar, $10 \mu \mathrm{m}$. $\boldsymbol{B}$, Confocal image of the stimulated stellate interneuron shown in $\boldsymbol{A}$ (biocytin labeled; green) and the responsive blood vessel (immunodetected for laminin; red). The stimulated stellate cell exhibits several neuronal processes coursing toward the reactive blood vessel. C, Mean vascular dilation induced by 2 min of evoked firing (black box) of stellate cells recorded at $20-25^{\circ} \mathrm{C}(n=6$; green) and at $30-35^{\circ} \mathrm{C}(n=5$; red), showing no statistical difference between the two conditions. $\boldsymbol{D}$, Spatiotemporal representation of the dilatory responses of the pial (top) and intraparenchymal (bottom) portions of a blood vessel induced by the evoked firing of a single stellate cell. Lowercase letters indicate the different locations of the measurements on the blood vessels (right). Scale bar, $10 \mu \mathrm{m}$. Note the spatially restricted dilation. $\boldsymbol{E}$, Electrophysiological recording of the stellate cell stimulated in $\boldsymbol{D}$ (top trace). An example of trains of action potentials evoked during the stimulation paradigm of the stellate cell (bottom trace) is shown.

\section{Enhancement of vasoconstrictions by NO}

A surprising observation was that lowering NO levels with L-NAME impaired the glutamate-induced vasoconstriction. It is unlikely this is attributable to nonspecific effects of L-NAME because it was also observed when NO levels are lowered with $\mathrm{Hb}$. The resistance of vasoconstrictions to $\mathrm{sGC}$ inhibition indicates sGC are not the site of action of NO in this enhancing effect. Rather, this could be caused by the reported ability of NO to inhibit P450 epoxygenase (Udosen et al., 2003), the synthesizing enzyme of the vasodilatory arachidonic acid metabolites epoxyeicosatrienoic acids. Interestingly, a similar enhancing effect of $\mathrm{NO}$ on vasocontracile responses has been observed in the 


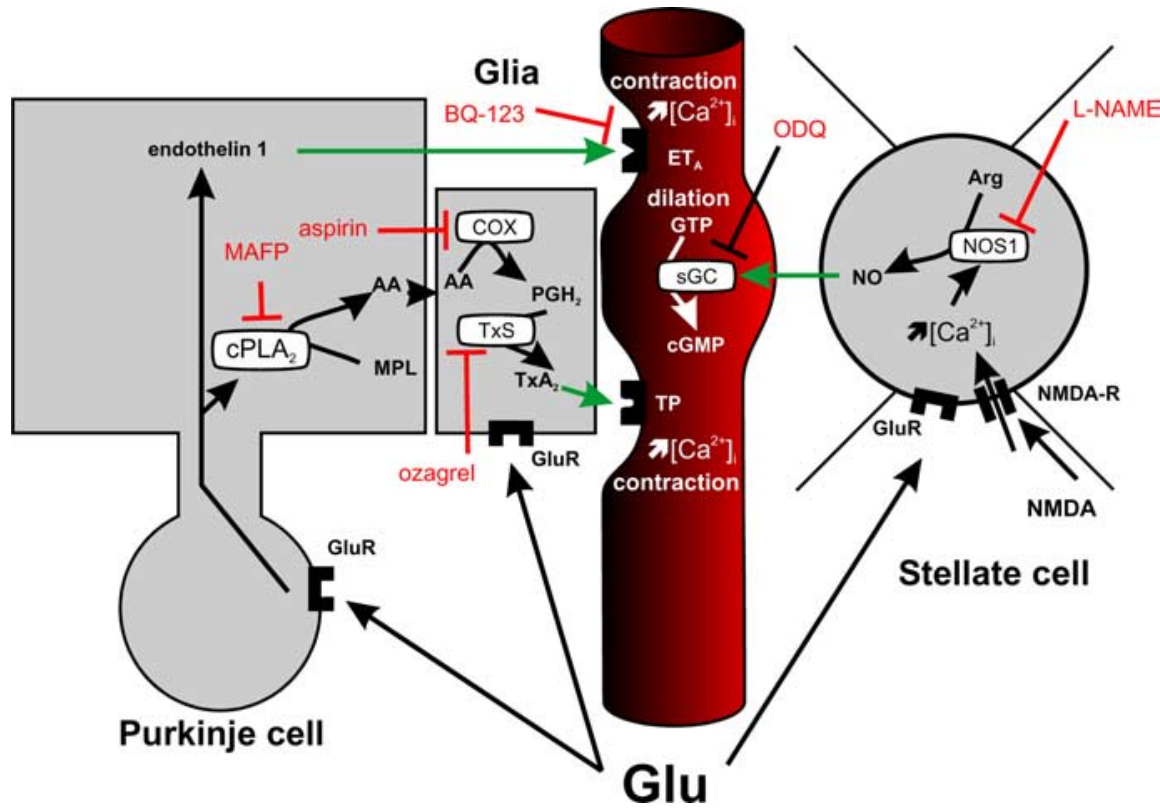

Figure 7. Hypothetic representation of the glutamatergic modulation of neurovascular coupling in the cerebellum. Activation of NMDA receptors (NMDA-R) on stellate cells by glutamate (Glu) induces NO synthesis and release (inhibited by L-NAME) and subsequent vasodilation of neighboring blood vessels through activation of SGC (inhibited by ODQ). In contrast, activation of glutamate receptors (GluR) on Purkinje cells induces endothelin 1 and arachidonic acid (AA) release from membrane phospholipids (MPL). Endothelin 1-induced vasoconstriction is blocked by the selective ETA receptor antagonist BQ-123. In glia, arachidonic acid is successively metabolized into prostaglandin $\mathrm{H} 2$ ( $\mathrm{PH}_{2}$ ) by cyclooxygenase (COX; inhibited by aspirin) and into thomboxane $\mathrm{A}_{2}\left(\mathrm{TxA}_{2}\right)$ by thomboxane synthase (TxS; inhibited by ozagrel). Release of $\mathrm{TXA}_{2}$ constricts neighboring blood vessels via thromboxane $\mathrm{A}_{2}$ receptors (TP). Although some of these pathways can also occur in Purkinje cells, they were omitted from the figure for clarity. Arg, Arginin.

hippocampus (Mulligan and MacVicar, 2004) and, more recently, in the retina (Metea and Newman, 2006).

\section{Strategic localization and connectivity of stellate cells within the molecular layer}

The in vivo observation that increases in the spiking rate of Purkinje cells is not correlated with an increase in CBF (Thomsen et al., 2004) is in agreement with our present findings showing Purkinje cells exert a vasoconstricting effect. On the contrary, our data and those of others (Yang et al., 2000) suggest that increases in CBF depend on the spiking of vasodilating NO-releasing stellate cells. Along this line, the decrease in spiking rate of Purkinje cells after parallel fiber stimulation (Caesar et al., 2003), which also excites stellate cells (Rancillac and Crepel, 2004), is correlated with a substantial increase in CBF (Caesar et al., 2003; Iadecola et al., 1997). Under this condition, the reduced spiking rate of Purkinje cells and hence of their vasocontractile effects may enhance the vasodilating action of stellate cells. Although Purkinje and stellate cells located near the same blood vessel receive the same group of excitatory parallel fibers, they are unlikely to be activated by the same individual fibers because they exhibit different receptive fields (Ekerot and Jorntell, 2001). However, in some physiological conditions, it possible that Purkinje cell and stellate cell activity stand against each other. In conclusion, our findings highlight the dynamic mechanisms that take place in the initiation of an integrated vascular response after local increases in neural activity that affects multiple neuronal populations, some of these exerting opposite effects on the local microvascular bed.

\section{References}

Amatore C, Arbault S, Bouret Y, Cauli B, Guille M, Rancillac A, Rossier J (2006) Nitric oxide release during evoked neuronal activity in cerebellum slices: detection with platinized carbon-fiber microelectrodes. Chem Phys Chem 7:181-187.

Bastianelli E (2003) Distribution of calciumbinding proteins in the cerebellum. Cerebellum 2:242-262.

Berthele A, Platzer S, Laurie DJ, Weis S, Sommer B, Zieglgansberger W, Conrad B, Tolle TR (1999) Expression of metabotropic glutamate receptor subtype mRNA (mGluR1-8) in human cerebellum. NeuroReport 10:3861-3867.

Bryan Jr RM, Marrelli SP, Steenberg ML, Schildmeyer LA, Johnson TD (2001) Effects of luminal shear stress on cerebral arteries and arterioles. Am J Physiol Heart Circ Physiol 280:H2011-H2022.

Caesar K, Gold L, Lauritzen M (2003) Context sensitivity of activity-dependent increases in cerebral blood flow. Proc Natl Acad Sci USA 100:4239-4244.

Carter AG, Regehr WG (2000) Prolonged synaptic currents and glutamate spillover at the parallel fiber to stellate cell synapse. J Neurosci 20:4423-4434.

Cauli B, Audinat E, Lambolez B, Angulo MC, Ropert N, Tsuzuki K, Hestrin S, Rossier J (1997) Molecular and physiological diversity of cortical nonpyramidal cells. J Neurosci 17:3894-3906.

Cauli B, Tong XK, Rancillac A, Serluca N, Lambolez B, Rossier J, Hamel E (2004) Cortical GABA interneurons in neurovascular coupling: relays for subcortical vasoactive pathways. J Neurosci 24:8940-8949.

Celio MR (1990) Calbindin D-28k and parvalbumin in the rat nervous system. Neuroscience 35:375-475.

Clark BA, Cull-Candy SG (2002) Activity-dependent recruitment of extrasynaptic NMDA receptor activation at an AMPA receptor-only synapse. J Neurosci 22:4428-4436.

Crepel F, Dhanjal SS, Sears TA (1982) Effect of glutamate, aspartate and related derivatives on cerebellar purkinje cell dendrites in the rat: an in vitro study. J Physiol (Lond) 329:297-317.

Ekerot CF, Jorntell H (2001) Parallel fibre receptive fields of Purkinje cells and interneurons are climbing fibre-specific. Eur $\mathrm{J}$ Neurosci 13:1303-1310.

Faraci FM, Breese KR (1993) Nitric oxide mediates vasodilatation in response to activation of $N$-methyl-D-aspartate receptors in brain. Circ Res 72:476-480

Fergus A, Lee KS (1997) Regulation of cerebral microvessels by glutamatergic mechanisms. Brain Res 754:35-45.

Fergus A, Jin Y, Thai QA, Kassell NF, Lee KS (1996) Tonic protein kinase $\mathrm{C}$-mediated vasoconstriction is unmasked when nitric oxide synthase is inhibited in cerebral microvessels. Neuroscience 74:927-934.

Filosa JA, Bonev AD, Nelson MT (2004) Calcium dynamics in cortical astrocytes and arterioles during neurovascular coupling. Circ Res 95:e73-e81.

Funk CD (2001) Prostaglandins and leukotrienes: advances in eicosanoid biology. Science 294:1871-1875.

Galarreta M, Hestrin S (2001) Electrical synapses between GABA-releasing interneurons. Nat Rev Neurosci 2:425-433.

Garthwaite J, Boulton CL (1995) Nitric oxide signaling in the central nervous system. Annu Rev Physiol 57:683-706.

Grandes P, Mateos JM, Ruegg D, Kuhn R, Knopfel T (1994) Differential cellular localization of three splice variants of the mGluR1 metabotropic glutamate receptor in rat cerebellum. NeuroReport 5:2249-2252.

Iadecola C (2004) Neurovascular regulation in the normal brain and in Alzheimer's disease. Nat Rev Neurosci 5:347-360.

Iadecola C, Zhang F (1996) Permissive and obligatory roles of NO in cere- 
brovascular responses to hypercapnia and acetylcholine. Am J Physiol 271:R990-R1001.

Iadecola C, Yang G, Ebner TJ, Chen G (1997) Local and propagated vascular responses evoked by focal synaptic activity in cerebellar cortex. J Neurophysiol 78:651-659.

Ignarro LJ, Cirino G, Casini A, Napoli C (1999) Nitric oxide as a signaling molecule in the vascular system: an overview. J Cardiovasc Pharmacol 34:879-886.

Karakossian MH, Otis TS (2004) Excitation of cerebellar interneurons by group I metabotropic glutamate receptors. J Neurophysiol 92:1558-1565.

Lambolez B, Audinat E, Bochet P, Crepel F, Rossier J (1992) AMPA receptor subunits expressed by single Purkinje cells. Neuron 9:247-258.

Lindauer U, Megow D, Matsuda H, Dirnagl U (1999) Nitric oxide: a modulator, but not a mediator, of neurovascular coupling in rat somatosensory cortex. Am J Physiol 277:H799-H811.

Liu SQ, Cull-Candy SG (2000) Synaptic activity at calcium-permeable AMPA receptors induces a switch in receptor subtype. Nature 405:454-458.

Llano I, Gerschenfeld HM (1993) Inhibitory synaptic currents in stellate cells of rat cerebellar slices. J Physiol (Lond) 468:177-200.

Llinas R, Sugimori M (1980) Electrophysiological properties of in vitro Purkinje cell dendrites in mammalian cerebellar slices. J Physiol (Lond) 305:197-213.

Lovick TA, Brown LA, Key BJ (1999) Neurovascular relationships in hippocampal slices: physiological and anatomical studies of mechanisms underlying flow-metabolism coupling in intraparenchymal microvessels. Neuroscience 92:47-60.

Metea MR, Newman EA (2006) Glial cells dilate and constrict blood vessels: a mechanism of neurovascular coupling. J Neurosci 26:2862-2870.

Mulligan SJ, MacVicar BA (2004) Calcium transients in astrocyte endfeet cause cerebrovascular constrictions. Nature 431:195-199.

Pardue S, Rapoport SI, Bosetti F (2003) Co-localization of cytosolic phospholipase A2 and cyclooxygenase-2 in Rhesus monkey cerebellum. Brain Res Mol Brain Res 116:106-114.

Petralia RS, Wenthold RJ (1992) Light and electron immunocytochemical localization of AMPA-selective glutamate receptors in the rat brain. J Comp Neurol 318:329-354.

Philippides A, Ott SR, Husbands P, Lovick TA, O'Shea M (2005) Modeling cooperative volume signaling in a plexus of nitric oxide synthaseexpressing neurons. J Neurosci 25:6520-6532.

Price CJ, Cauli B, Kovacs ER, Kulik A, Lambolez B, Shigemoto R, Capogna M (2005) Neurogliaform neurons form a novel inhibitory network in the hippocampal CA1 area. J Neurosci 25:6775-6786.

Rancillac A, Crepel F (2004) Synapses between parallel fibres and stellate cells express long-term changes in synaptic efficacy in rat cerebellum. J Physiol (Lond) 554:707-720.

Rodrigo J, Springall DR, Uttenthal O, Bentura ML, badia-Molina F, RiverosMoreno V, Martinez-Murillo R, Polak JM, Moncada S (1994) Localization of nitric oxide synthase in the adult rat brain. Philos Trans R Soc Lond B Biol Sci 345:175-221.

Roy CS, Sherrington C (1890) On the regulation of the blood supply of the brain. J Physiol (Lond) 11:85-108.

Sagher O, Zhang XQ, Szeto W, Thai QA, Jin Y, Kassell NF, Lee KS (1993) Live computerized videomicroscopy of cerebral microvessels in brain slices. J Cereb Blood Flow Metab 13:676-682.

Sagher O, Jin Y, Thai QA, Fergus A, Kassell NF, Lee KS (1994) Cerebral microvascular responses to endothelins: the role of ETA receptors. Brain Res 658:179-184.

Sluck JM, Lin RC, Katolik LI, Jeng AY, Lehmann JC (1999) Endothelin converting enzyme-1-, endothelin-1-, and endothelin-3-like immunoreactivity in the rat brain. Neuroscience 91:1483-1497.

Southam E, East SJ, Garthwaite J (1991) Excitatory amino acid receptors coupled to the nitric oxide/cyclic GMP pathway in rat cerebellum during development. J Neurochem 56:2072-2081.

Stella N, Tence M, Glowinski J, Premont J (1994) Glutamate-evoked release of arachidonic acid from mouse brain astrocytes. J Neurosci 14:568-575.

Stephenson DT, Manetta JV, White DL, Chiou XG, Cox L, Gitter B, May PC, Sharp JD, Kramer RM, Clemens JA (1994) Calcium-sensitive cytosolic phospholipase A2 (cPLA2) is expressed in human brain astrocytes. Brain Res 637:97-105.

Thomsen K, Offenhauser N, Lauritzen M (2004) Principal neuron spiking: neither necessary nor sufficient for cerebral blood flow in rat cerebellum. J Physiol (Lond) 560:181-189.

Udosen IT, Jiang H, Hercule HC, Oyekan AO (2003) Nitric oxideepoxygenase interactions and arachidonate-induced dilation of rat renal microvessels. Am J Physiol Heart Circ Physiol 285:H2054-H2063.

Wood J, Garthwaite J (1994) Models of the diffusional spread of nitric oxide: implications for neural nitric oxide signalling and its pharmacological properties. Neuropharmacology 33:1235-1244.

Yang G, Chen G, Ebner TJ, Iadecola C (1999) Nitric oxide is the predominant mediator of cerebellar hyperemia during somatosensory activation in rats. Am J Physiol 277:R1760-R1770.

Yang G, Huard JM, Beitz AJ, Ross ME, Iadecola C (2000) Stellate neurons mediate functional hyperemia in the cerebellar molecular layer. J Neurosci 20:6968-6973.

Zonta M, Angulo MC, Gobbo S, Rosengarten B, Hossmann KA, Pozzan T, Carmignoto G (2003) Neuron-to-astrocyte signaling is central to the dynamic control of brain microcirculation. Nat Neurosci 6:43-50. 